\title{
Anogenital Warts in Childhood - Always a Marker for Sexual Abuse?
}

\section{Anogenitale Kondylome im Kindesalter - immer ein Hinweis auf einen sexuellen Übergriff?}

Authors

Affiliations
S. Bussen ${ }^{1}$, M. Sütterlin ${ }^{1}$, U. Schmidt ${ }^{1}$, D. Bussen ${ }^{2}$

${ }^{1}$ Universitätsfrauenklinik Mannheim, Mannheim

2 Deutsches End- und Dickdarmzentrum Mannheim, Mannheim

\section{Schlüsselwörter}

- Condylomata acuminata

- Feigwarzen

- HPV-Infektion

- sexueller Missbrauch

Key words

- condylomata acuminata

- genital warts

- HPV infection

- sexual abuse

\section{received 21.8.2011 \\ revised 14.11.2011 \\ accepted 16.11.2011}

\section{Bibliography}

DOI http://dx.doi.org/

10.1055/s-0031-1280417

Geburtsh Frauenheilk 2012; 72 :

43-48 (c) Georg Thieme

Verlag KG Stuttgart · New York ISSN 0016-5751

\section{Correspondence}

PD Dr. Stefanie Bussen

Universitätsfrauenklinik Theodor-Kutzer-Ufer 1-3 68167 Mannheim

stefanie.bussen@universitaetsmedizin-mannheim.net

\section{Abstract \\ $\nabla$}

Human papilloma viruses (HPV) are common pathogens associated with a wide range of cutaneous and mucosal infections in childhood. Different HPV types can cause common warts and anogenital warts. Condylomata acuminata in children may be, but are not necessarily, an indicator of sexual abuse. Each individual case therefore requires careful examination, with consideration of other possible means of transmission. Diagnosis of anogenital warts is generally by means of clinical examination. Additional histological, serological or molecular genetic investigation may be indicated occasionally. The high rate of spontaneous remission and the rate of recurrence after treatment should be considered. The available topical and surgical treatment options are discussed.

\section{Zusammenfassung \\ $\nabla$}

Bei den humanen Papillomviren (HPV) handelt es sich um weitverbreitete Erreger, die auch im Kindesalter eine Vielzahl von Haut- und Schleimhautinfektionen verursachen können. Infektionen mit unterschiedlichen HPV-Typen können Hautwarzen oder anogenitale Kondylome hervorrufen. Condylomata acuminata bei Kindern können, aber müssen nicht hinweisend für sexuellen Missbrauch sein. Daher bedarf es unter Berücksichtigung anderer Übertragungsmöglichkeiten einer sehr sorgfältigen Überprüfung des Einzelfalls. Die Diagnose anogenitaler Kondylome wird in der Regel durch die klinische Untersuchung gestellt. Histologische, serologische oder molekulargenetische Zusatzdiagnostik ist nur in Einzelfällen sinnvoll. Bei der Indikation zur Therapie sind die hohe Spontanremissionsrate sowie die posttherapeutische Rezidivrate zu berücksichtigen. Die zur Verfügung stehenden topischen und chirurgischen Therapieoptionen werden dargestellt.

\section{Introduction \\ $\nabla$}

Condylomata acuminata, also referred to as pointed condylomata or genital warts, are the most common types of benign tumour affecting the external anogenital region. Histologically, they are fibroepitheliomas [1,2]. Condylomata are virally induced. In more than $90 \%$ of cases, infection is through human papilloma viruses (HPV) of low-risk groups 6 or 11, but there has also been evidence of HPV-1, -2, -4, -7, -27, -57, -60 and -63 in condylomata [3]. There may be great variation in the clinical appearance of an anogenital HPV infection. Most often, there are papules the size of a pinhead, up to several centimetres in size, which are generally whitish, grey-brown or reddish in colour ( Fig. 1). Condylomata tend to disseminate and become multifocal, occasionally large tumorous masses form and rarely there is a single growth $[3,4]$. Whereas in older children and adults the vulva, the perianal region, the urethra, the shaft of the penis and, more rarely, the inguinal and pubic region are known to be preferred sites, children in the first and second year of life are predominantly affected in the perianal region. Girls are affected three times more often than boys [5-7].

Condylomata are frequently asymptomatic and are only diagnosed as incidental findings. They can cause itching, burning or weeping in the areas of skin affected. Occasionally, slight bleeding (on contact) is observed. However, for adult patients the clinical manifestation of an HPV infection is associated with a definite reduction in quality of life [8]. This is seen in the stigmatisation of a disease transmitted by sexual intercourse and its 


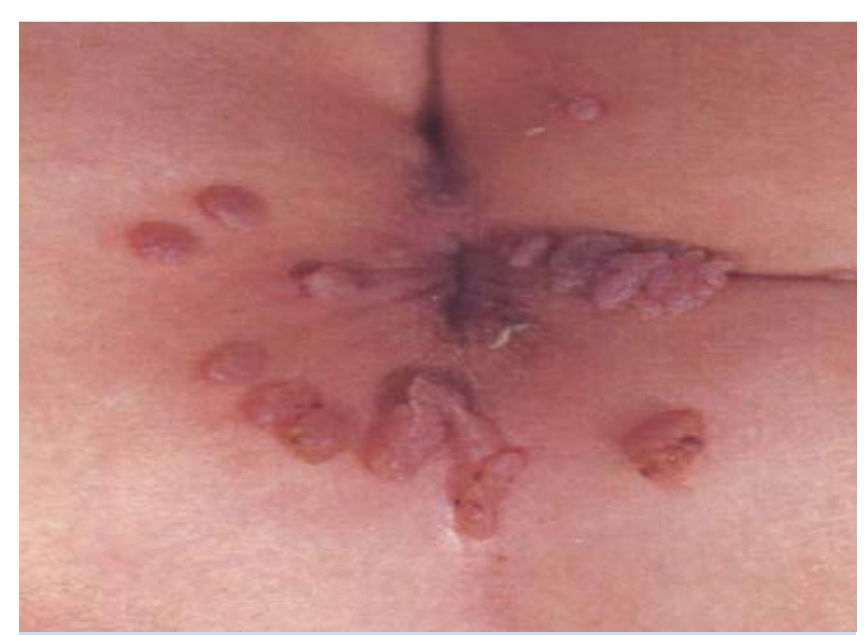

Fig. 1 Anogenital condylomata acuminata in a girl aged 5 years and 6 months.

negative effects on intimate contact. When there is evidence of anogenital condylomata in childhood, this uncertainty also applies to doctors who are not familiar with this subject in detail since, in the case of an infection which is predominantly transmitted by direct skin-to-skin contact and which is manifested in the anogenital region, inevitably the suspicion arises that the child involved has been subjected to sexual abuse, and the search for appropriate suspects starts. The parents have a great need for information and communication with the treating doctor. They also want their child to have effective treatment which is not too stressful and is pain-free as far as possible. They fear that the treatment will not be successful, that there will be relapses and are worried about the uncertainty of the duration of the treatment. These fears often lead to psychosocial stress with a subjective reduction in quality of life $[9,10]$.

\section{Paediatric Gynaecological Aspects of Anogenital Condylomata \\ $\nabla$}

Anogenital condylomata can be found in $1-2 \%$ of the adult population. Since 1971, the incidence has increased by a factor of 11 in women and a factor of 8 in men $[1,11]$. The peak age for the disease is from the 20th to the 24th year of life [12]. Latent HPV infections, with laboratory evidence of viral HPV DNA but no clinical, histological or cytological abnormalities, occur in approximately $10 \%$ of adults. $20 \%$ of the female population between 20 and 25 have subclinical HPV infections in the genital tract [1215]. The proportion of HPV antibody-positive persons is estimated at $60 \%$ of the population $[16,27]$. Human papilloma viruses therefore represent a widely diffusive pathogen in the population as a whole. To date, there is little data on the incidence of anogenital condylomata in childhood. Up to 1990 , only 74 cases of the disease in infants had been published. After investigating a small collective of 211 healthy male and female preschool children between 5 and 6 years of age, Myrhre et al (2003) [18] published the only study to date of the prevalence of anogenital condylomata in childhood in the normal population. The authors observed 4 girls (1.8\%) with anogenital condylomata [18].

\section{Non-sexual Transmission of Human Papilloma Viruses in Childhood \\ $\nabla$}

Infection is predominantly by direct skin-to-skin contact. However, in addition to sexual transmission, which is the most frequent transmission route in adults, non-sexual transmission routes through close skin contact are also described. HPV infection can also occur in children through non-sexual transmission [19]. In this case, the infection route may be antenatal, perinatal or postnatal $[20,21]$. Transmission of the HPV infection from the mother to her child during birth can lead either to anogenital condylomata or to laryngeal papillomas $[6,22]$. This perinatal infection of the child can arise both from clinically manifest and from subclinical lesions. Since the incubation time for condylomata can vary from a minimum of 3 weeks to several months, a manifestation in the first months of life does not exclude an infection which has already occurred in the antenatal period $[21,23]$. One further possible non-sexual postnatal infection route is smear infection via the infant's caregiver. Given the high prevalence of virus carriers in the total population and the infant's intensive care requirements, particularly in the anogenital region, there is frequent skin-to-skin contact. This is in keeping with the observation that, in both male and female infants under 2 years of age, the typical preferred site is the perianal region [23]. The clinical manifestation of an HPV infection is also dependent on predisposing local factors such as moisture, macerations or epithelial lesions, conditions which often occur with infants in nappies with physiological incontinence, frequently intermittent anogenital eczema or dermatitis $[6,23]$.

The autoinoculation and heteroinoculation of human papilloma viruses, for example originating from warts on the fingers (particularly HPV type 2) of the child himself or the reference person, also represents a non-sexual transmission route $[21,24]$.

\section{Paediatric Gynaecological Aspects of Sexual Abuse $\nabla$}

According to police criminal statistics, 11867 cases of sexual abuse of children under the age of 14 were reported in Germany in 2010. In the same period, 9326 sexual violations of adolescents were recorded [25]. The clearance rate was between $73 \%$ for children and $91 \%$ for adolescents. However, only $13 \%$ of the legal proceedings resulted in conviction of the perpetrator [26-28]. In addition to these known criminal offences against the sexual selfdetermination of children and adolescents, the estimated number of unreported cases is thought by experts to be 10-20 times higher [29-32].

The suspicion of sexual abuse can arise in various ways. Direct or indirect statements by the child, abnormal behaviour, physical signs on the child, observations of caregivers or disturbed family interaction can lead to the suspicion of sexual abuse $[26,30,31$, $33,34]$. The symptoms noticeable in the paediatric gynaecological examination are only rarely pathognomonic of sexual abuse having taken place. Sexual abuse can be demonstrated by physical examination in less than $10 \%$ of children [26,33-37]. Circumstances providing clear evidence of sexual abuse, even without a statement by the child, include acute trauma of the anogenital tract (lacerations, haematomas, deep perineal tears) without clear evidence of accidental aetiology, infections with gonococci, syphilis and HIV after ruling out perinatal transmission, trichomoniasis after the 1st year of life, a chlamydia-trachomatis infection after the 3rd year of life, as well as evidence of spermatozoa 
on the child's body and pregnancy $[26,33]$. Thus, in most cases, the suspicion is based on a combination of non-specific individual symptoms [21]. Reductions of the hymenal edge no longer have a part to play in the diagnosis; however, clefts in the sense of complete transection of continuity are diagnostic and notches must be taken into account, depending on the location, the age group and depth in relation to overall height of the hymenal edge [33].

When investigating sexual abuse, care of the child concerned is paramount and takes precedence over the interests of parents and other persons involved with the child or institutions. In addition to the professional uncertainty of persons who are only rarely confronted with this subject, personal concern is also always a factor. Therefore, anyone having professional contact with victims of sexual abuse should be aware that precipitous and overhasty remedial measures, prejudgement or speculations can do more harm than good. On the other hand, dealing with the child concerned empathetically and considerately, and carrying out a careful investigation with comprehensive documentation of the findings obtained are of great benefit [33].

\section{Sexual Transmission of Human Papilloma Viruses in Childhood \\ $\nabla$}

The investigation with the largest collective of children examined was published by Ingram et al. in 1992 [38]. Although the acceptance criterion was suspected sexual abuse, it is not to be deduced from the methodology of this study, on which this suspicion is based, whether the history or clinical findings led to presentation at a special clinic. 1538 children (of which $85 \%$ were girls and $15 \%$ boys) aged between 1 and 12 years were examined. Of this total collective, 28 children were found to have condylomata acuminata in the anogenital region. This corresponds to a prevalence of anogenital condylomata in an at-risk collective of children questionably subjected to sexual abuse of $1.8 \%$. Following differentiated multidisciplinary investigation, the suspicion of sexual abuse was not corroborated for 69 out of 1538 children (4.5\%). Of the total of 28 children with condylomata, 16 children were in this group. This means that in $57 \%$ of the children with anogenital condylomata, the HPV infection resulted from non-sexual transmission. For 8 of these children, taking into account the available medical findings for the mother, perinatal transmission was plausible. For the remaining 1469 children (95.5\%) of the total collective, the initial suspicion that the children had been the victims of sexual abuse was confirmed in the course of further exploration and investigation. Of the 28 children with condylomata, 12 were in this group. This meant that in $43 \%$ of the children with anogenital condylomata the HPV infection was caused by sexual transmission. For 2 of these children, taking into account the available medical findings for the mother, perinatal transmission was assumed. The age distribution of the 28 children with anogenital condylomata in relation to proven sexual

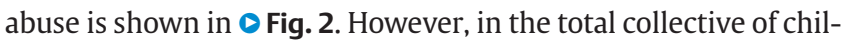
dren with proven sexual abuse, the prevalence was only $0.8 \%$ (12/ 1538 children). Although there was rarely evidence of anogenital condylomata in children who were subjected to sexual abuse, the authors were able to establish a very significant relationship between the age of the children affected and the probability of sexual transmission.

16 of the children with condylomata were younger than 5 years. The supposed sexual abuse was confirmed in only 3 of these chil-

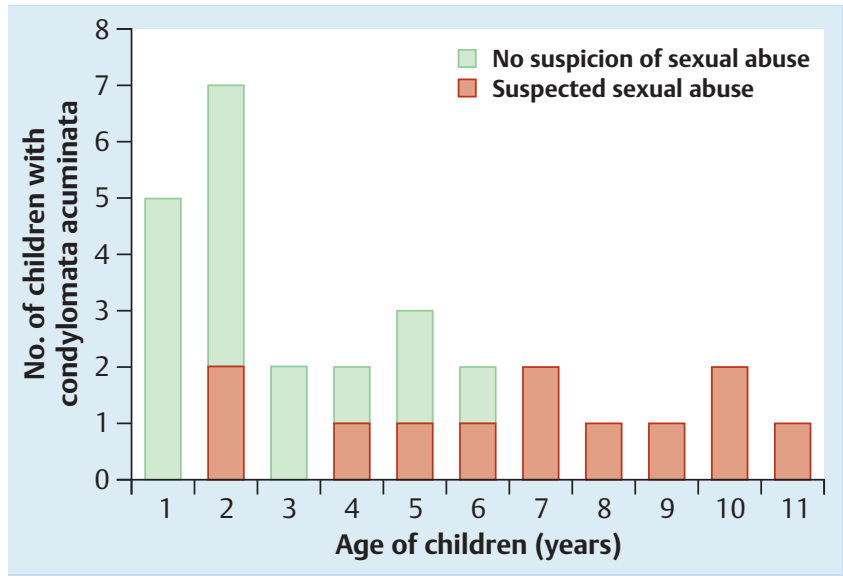

Fig. 2 Age distribution of children with anogenital condylomata acuminata in relation to proven sexual abuse according to Ingram et al (1992) [38].

dren (20\%). Of the 12 children aged between 5 and 12 years who were found to have condylomata, sexual transmission was taken to be the cause in 9 children (75\%). On analysing the 5 children who were 8 to 12 years old at the time of diagnosis, the HPV infections were caused by sexual abuse in each case.

A second extensive study was published by the working group Sinclair et al. in 2005 [22]. Here, too, the collective investigated consisted of a total of 1640 girls and boys up to 13 years of age who presented to a special interdisciplinary clinic due to suspected sexual abuse. In 74 children (4.5\%), anogenital condylomata were diagnosed. Only 55 of these 74 children were evaluated with regard to sexual abuse. In 17 of these 55 children (31\%), the suspicion that they had been victims of sexual abuse was corroborated. The data published do not provide any detailed information regarding the prevalence of condylomata in the various age groups.

An informative study was published by Jones et al. (2007) [19], in which the environment of 131 girls and boys aged 6 months to 9 years with anogenital condylomata was evaluated for indications of sexual or non-sexual transmission. In 66 of the 131 children (50\%), the mother's previous history pointed to anogenital condylomata or cervical dysplasia. For the 81 of the 131 children of this collective who had siblings, $40 \%$ of the siblings also had condylomata. Thus, in 98 of the 131 children (75\%), the history pointed to non-sexual transmission. All the children were taken for interdisciplinary examination to rule out sexual abuse. After careful paediatric psychiatric investigation, in only 3 of the 131 children (2.3\%) with anogenital condylomata was the suspicion of sexual violation and sexual transmission of human papilloma viruses confirmed on the basis of indicators in the history or further clinical findings. Two of these children had a negative maternal history and siblings without condylomata.

\section{Statements by National and International Professional Associations}

$\nabla$

These and other investigations carried out on smaller collectives [38-41] have led to the recommendations of various professional associations which are basically in agreement. These are summarised as follows: 
American Academy of Pediatrics: The evaluation of sexual abuse in children (2005) [35]:

"A clinical examination for anogenital condylomata should be carried out, but no HPV test. The evidence is considered to be suspect if the child is older than 24 months."

Guidelines on child abuse and neglect by the Deutsche Gesellschaft für Sozialpädiatrie und Jugendmedizin [German Society for Social Paediatrics and Adolescent Medicine], the Deutsche Gesellschaft für Kinderheilkunde und Jugendmedizin [German Society for Paediatric and Adolescent Medicine] and the Deutsche Gesellschaft für Kinderchirurgie [German Society for Paediatric Surgery], 9/2008 [42]:

"Anogenital condylomata are of unclear specificity for sexual transmission. In the absence of a clear and unambiguous statement by the child, the evidence is to be treated as a dubious finding and should be carefully assessed."

\section{Guidelines of the Deutsche Gesellschaft für Kolo-} proktologie [German Society for Coloproctology]: Anal warts (2008) [43]:

"Sexual abuse as the cause of genital warts in children does occur, but is far less common than previously supposed".

\section{Guidelines of the Deutsche Gesellschaft für Urologie [German Society for Urology]: Investigation and treatment of genital diseases caused by human papilloma viruses (HPV) (2001) [44]:}

"Sexual abuse can lead to warts in the anogenital region of children, but careful and guarded investigation must be carried out in each individual case where there are other transmission possibilities."

Guidelines of the Deutsche STD-Gesellschaft [German STD Society] in collaboration with the Deutsche Dermatologische Gesellschaft [German Dermatology Society] and the Paul-Ehrlich Institute: Condylomata acuminata and other disease patterns of the genitals, anus and urethra associated with HPV (2007) [3]:

"Sexual abuse can lead to warts in the anogenital region of children. Condylomata acuminata in children may be, but are not always, an indicator for sexual abuse. If this suspicion is corroborated (abnormal behaviour by the child, signs of violence, etc.), a paediatrician and a specially experienced child psychologist should always be called in, in addition to a dermatologist."

\section{Diagnostics and Differential Diagnoses}

$\nabla$

With their typical appearance, condylomata are generally diagnosed by clinical examination. Histological investigation is only indicated in the case of uncertain clinical diagnosis, resistance to therapy, early recurrence, ulcerations, increasing pigmentation, immunosuppression or isolated skin eruptions larger than $1 \mathrm{~cm}$ $[1,2,45,46]$. One exception which should be mentioned is the investigation of solitary verruciform genital warts as further clarification of possible malignancy $[1,3]$. Serological HPV investigation is not meaningful $[1,3,23]$. The routine use of acetic acid is not necessary and therefore, in view of the painfulness of this examination in a very sensitive area of the body, should be avoided, particularly in children. Molecular diagnostic HPV typing is also not indicated in the standard investigations. In the case of inoculation, HPV types 2, 27 and 57 can cause condylomata via warts on the fingers. Although in individual cases evidence of these types can undermine the suspicion of sexual abuse, as the specificity and sensitivity of the available tests has not been evaluated, they are not recommended for providing evidence in cases where sexual abuse is suspected $[21-23,33,34,41]$.

Differential diagnoses, which must be taken into account in investigating anogenital verruciform lesions, are listed in $\bigcirc$ Table 1 $[1,3,43,44]$. Special attention should be paid to the anatomical deviation from the norm of micropapillomatosis, with which we see physiological skin appendages, so-called genital papillae [47].

\section{Treatment Options}

$\nabla$

There is currently no antiviral treatment available which is specifically directed against HPV. None of the treatment processes available can remove genital warts reliably and ensure freedom from warts. Irrespective of the treatment chosen, despite successful treatment, HPV DNA can remain latent in the tissue and lead to the recurrence of visible lesions. After initially successful treatment, there is further condylomata formation within 6 months in up to $70 \%$ of cases. The topical treatment options currently available are listed in 0 Table $2[3,43,44,48-50]$. It should be emphasised that none of these preparations is licensed for use with children or adolescents. There are numerous case histories on the use of imiquimod for children from the age of 6 months [50-54]. O Table 3 presents an overview of the current surgical treatment options $[8,17,43,55-57]$. None of the treatment meth-

Table 1 Differential diagnoses of anogenital condylomata [1, 3, 43, 44].

\begin{tabular}{|c|c|}
\hline Anatomical variants & $\begin{array}{l}\text { papillomatosis } \\
\text { ectopic sebaceous glands } \\
\text { skin appendages }\end{array}$ \\
\hline Benign skin tumour & $\begin{array}{l}\text { fibromas } \\
\text { angiokeratomas } \\
\text { seborrhoeic warts } \\
\text { perianal skin tags }\end{array}$ \\
\hline $\begin{array}{l}\text { Inflammatory } \\
\text { dermatoses }\end{array}$ & $\begin{array}{l}\text { condylomata lata } \\
\text { mollusca contagiosa } \\
\text { genital herpes }\end{array}$ \\
\hline Malignant tumours & $\begin{array}{l}\text { - intraepithelial neoplasias } \\
\text { verrucous squamous epithelial carcinoma } \\
\text { - malignant melanoma }\end{array}$ \\
\hline
\end{tabular}

Table 2 Topical therapy options for the treatment of anogenital condylomata $[3,43,44,48-50]$.

\begin{tabular}{|l|l|}
$\begin{array}{l}\text { Podophyllo- } \\
\text { toxin cream }\end{array}$ & antimitogenic substance, reduction of virus activity \\
$0.15 \%$ & by local necrosis \\
& twice daily for 3 days, then pause for 4 days \\
\hline Imiquimod & repeat up to a maximum of four cycles \\
cream $5 \%$ & stimulation of the cellular immune response to HPV \\
& apply on alternate days in the evening, wash off in the \\
& morning, for a maximum of 16 weeks \\
\hline Polyphenon E & extract of green tea (Camilla sinensis, so-called tea \\
& catechin) \\
& activation of T lymphocytes, antioxidative effect, \\
& inhibition of virus receptor binding \\
& $3 \times$ daily without a pause in treatment, max. 16 weeks
\end{tabular}


Table 3 Surgical therapy options for the treatment of anogenital condylomata $[8,17,43,56-58]$.

\begin{tabular}{|c|c|}
\hline $\begin{array}{l}\mathrm{CO}_{2} \text { laser } \\
\text { vaporisation }\end{array}$ & $\begin{array}{l}\text { - spot width } 1-1.5 \mathrm{~mm} 15 \mathrm{~W} \\
\text { - minimal heat damage } \\
\text { - expensive equipment }\end{array}$ \\
\hline $\begin{array}{l}\text { Wet field } \\
\text { excision }\end{array}$ & $\begin{array}{l}\text { removal with the monopolar loop of the electro- } \\
\text { cautery device with wetting of the surface with } \\
\text { water or gel fluid-supported electrocoagulation } \\
\text { with simultaneous application of water or laser } \\
\text { - risk of deep destruction }\end{array}$ \\
\hline $\begin{array}{l}\text { Scissors } \\
\text { excision }\end{array}$ & $\begin{array}{l}\text { - removal with scissors } \\
\text { simple availability }\end{array}$ \\
\hline Cryotherapy & $\begin{array}{l}\text { - application of cold with liquid nitrogen } \\
\text { - weekly to two-weekly } \\
\text { - mostly 2-3 treatments }\end{array}$ \\
\hline
\end{tabular}

ods is clearly advantageous in comparison with any other [58]. All the forms of treatment are associated with more or less pronounced local skin reactions, such as erythema, oedema or erosions, or more or less clearly pronounced symptoms, such as burning, itching or pain, which make it difficult to achieve optimal compliance, particularly with the smaller paediatric patients. In view of these side effects of treatment, the slight symptoms, the high spontaneous remission rate (up to $35 \%$ after 4 months, up to $50 \%$ after 12 months, up to $90 \%$ after 24 months) $[58,59]$ and the high recurrence rate after treatment, the option of watchful waiting is to be considered in each individual case [24, $60,61]$. In the case of extensive local findings, and depending on the symptoms, treatment may be indicated, taking into account the psychological strain, which is generally not felt by the young patients, but is experienced all the more so by their parents.

\section{Future prospects}

After several decades of rapidly rising subclinical and clinical HPV infections, it is hoped that, following the introduction of the quadrivalent HPV-6,11,16,18 vaccine in October 2006, there will be a reduction in the number of cases in the coming decades and that the recommendation still given by the Center for Disease Control (CDC) in 2010 [58] that only refraining from sexual contact can prevent HPV infection will lose its relevance. In Australia, 12 months after the introduction of the vaccination programme, with a vaccination rate of $65-70 \%$ in women under 28 years of age, Donovan et al. (2011) [62] observed a $48 \%$ reduction in the rate of new condylomata infections. Since the recommendation by the Standing Vaccination Committee (STIKO) at the Robert Koch Institute in March 2007 [63], confirmed in August 2009 [64], that girls aged 12 to 17 should be vaccinated before their first sexual intercourse to prevent HPV-associated neoplasias, a vaccination rate of approximately $30 \%$ has been achieved to date $[65,66]$. This rate needs to be increased, but in the collective vaccinated with the quadrivalent HPV-6,11,16,18 vaccine we are certain to see a reduction in the rate of new condylomata infections in the near future $[67,68]$.

\section{Summary for Practice}

Condylomata acuminata in children may be, but are not necessarily, an indicator of sexual abuse. Each individual case therefore requires very careful examination, with consideration of other possible means of transmission. Without a clear statement by the child and further indicators, the presence of anogenital condylomata alone is not to be seen as evidence of sexual abuse. The at-risk collective in respect of HPV infection through sexual transmission is taken to be children first infected at $>4$, and particularly $>8$ years of age without any known maternal HPV infection and without any known ambient infection with common warts.

Diagnosis is by means of clinical examination. HPV typing or serological examination is not recommended.

In the event of condylomata in childhood, there should be a paediatric gynaecological examination in relation to abuse-associated findings and screening for coexistent sexual diseases, a history should be taken with regard to maternal or familial condylomata and questions should be asked either verbally or by means of a questionnaire regarding any abnormalities exhibited by the child $[69,70]$.

\section{Conflict of Interest}

\section{$\nabla$}

The authors declare that they do not have any financial relationship with any company associated with the article.

\section{References}

1 Gross G. Differentialdiagnostik anogenitaler Condylomata acuminata. Hautarzt 2009; 60: 465-471

2 Hillemanns P, Mehlhorn G, Rinnau F et al. HPV-Infektion: Impfung, Diagnostik und Therapie. Geburtsh Frauenheilk 2007; 67: R1-R28

3 Gross G. AWMF Nr 059/001 Leitlinie der Deutschen STD-Gesellschaft (DSTG) in Zusammenarbeit mit der Deutschen Dermatologischen Gesellschaft Condylomata acuminata und andere HPV-assoziierte Krankheitsbilder von Genitale, Anus und Harnröhre. Hautarzt 2007; 58: 179-186

4 Geyer A, Röcken M, Strölin A. Dermatologie: Hautveränderungen und Erkrankungen der Haut in der Schwangerschaft. Geburtsh Frauenheilk 2006; 66: 910-913

5 Sinclair KA, Woods CR, Sinal SH. Veneral warts in children. Pediatr Rev 2001; 32: 115-121

6 Mammas IN, Sourvinos G, Spandidos D. Human papilloma virus (HPV) infection in children and adolescents. Eur J Pediatr 2009; 168: 267-273

7 Culton DA, Morrell DS, Burkhart CN. The management of condylomata acuminata in the pediatric population. Pediatr Ann 2009; 38: 368-372

8 Weyandt GH. Neue operative Ansätze zur Sanierung anogenitaler HPVInfektionen. Hautarzt 2011; 62: 28-33

9 Mortensen GI, Larsen HK. The quality of life of patients with genital warts: a quality study. BMC Public Health 2010; 10: 113

10 Mortensen GL. Long-term quality of life of genital warts - a followstudy. Dan Med Bull 2010; 57: A4140

11 Gieseking F, Petry KU, Hillemanns P. Incidence, prevalence and costs of treating genital warts in the pre-HPV vaccine era in Germany. Value Health 2005; 8: 64-65

12 Trottier H, Burchell AN. Epidemiology of mucosal human papillomavirus infection and associated diseases. Public Health Genomics 2009; 12: $291-307$

13 Bachmann A, Zottler K, Iftner Tet al. HPV-Infektion und Zervixkarzinom - eine Übersicht. Geburtsh Frauenheilk 2007; 67: 438-442

14 Kjaer SK, Tran TN, Sparen P. The burden of genital warts: a study of nearly 70000 women from the general female population in the 4 nordic countries. J Infect Dis 2007; 196: 1447-1454

15 Ikenberg H. Kongressbericht „HPV 2007“ und 57.Jahrestagung der STD-Gesellschaft. Geburtsh Frauenheilk 2008; 68: 103-104

16 Kraut AA, Schink T, Schulze-Rath R et al. Incidence of anogenital warts in Germany: a population based cohort study. BMC Infect Dis 2010; 10: 360-367

17 Schmidt-Petruschkat S. Zunahme von Geschlechtskrankheiten in Deutschland - ein bislang unbeachtetes Risiko? Geburtsh Frauenheilk 2009; 69: 429-432

18 Myhre AK, Dalen A, Berntzen Ket al. Anogenital papillomavirus in nonabused children. Act Pediatr 2003; 92: 1445-1452 
19 Jones V, Smith SJ, Omar HA. Nonsexual transmission of anogenital warts in children: a retrospective analysis. Scientific World J 2007; 7: 18961899

20 Syrjanen S, Puranen M. Human papillomavirus infections in children: the potential role of maternal transmission. Crit Rev Oral Biol Med 2000; 11: 259-274

21 Hammerschlag MR, Guillen CD. Medical and legal implications of testing for sexually transmitted infections in children. Clin Microbiol Review 2010; 23: 493-506

22 Sinclair K, Woods CR, Kirse DJ et al. Anogenital and respiratory tract human papillomavirus infections among children: age, gender and potential transmission through sexual abuse. Pediatr 2005; 116: 815-825

23 Marcoux D, Nadeau K, McCuaig C. Pediatric anogenital warts: a 7-year review of children referred to a tertiary-care hospital in Montreal, Canada. Pediatr Dermatol 2006; 23: 199-207

24 Sinal SH, Woods CR. Human papillomavirus infections of the anogenital and respiratory tract in young children. Sem Pediatr Infect Dis 2005; 16: 306-316

25 Bundeskriminalamt. Polizeiliche Kriminalstatistik Bundesrepublik Deutschland. Berichtsjahr 2010 - Straftaten gegen die sexuelle Selbstbestimmung. http://www.bka.pks2010lmkKurzbericht.pdf; last access: 1.8 .2011

26 Bussen S, Rehn M, Haller A et al. Kindergynäkologische Aspekte des sexuellen Missbrauchs. Zentralbl Gynäkol 2001; 123: 562-567

27 Vogt-Hell C. Kinder- und Jugendgynäkologie. Was tun bei sexuellem Missbrauch? Geburtsh Frauenheilk 2004; 64: 852-855

28 Anthuber S. 1. Münchner Symposium für Kinder- und Jugendgynäkologie. Geburtsh Frauenheilk 2004; 64: 645-646

29 Berg $D$. Essentials zur neuen S1-Leitlinie zum Umgang mit Frauen nach sexueller Gewalt. Geburtsh Frauenheilk 2010; 70: 151

30 Haist M. Allgemeine Gynäkologie - Teenagersprechstunde. Geburtsh Frauenheilk 2006; 66: 1204-1205

31 Jundt K, Schönfeld K, Peschers UM. Sexueller Missbrauch von Mädchen und Frauen - Ein Thema, das Frauenärzte nicht betrifft? Geburtsh Frauenheilk 2006; 66: 795-796

32 Smith DW. Delay in disclosure of childhood rape. Child Abuse Neglect 2000; 24: 273-287

33 Adams J. Guidelines for medical care of children evaluated for suspected sexual abuse: an update for 2008. Curr Opin Obstet Gynecol 2008; 20: 435-441

34 Bechtel $K$. Sexual abuse and sexually transmitted infections in children and adolescents. Curr Opin Pediatr 2010; 22: 94-99

35 Kellogg $N$. The evaluation of sexual abuse in children. Pediatr 2005; 116: 506-512

36 Leeners B, Görres G, Hukic E et al. Probleme in der Schwangerschaft, während der Geburt und im Wochenbett nach sexueller Gewalterfahrung. Geburtsh Frauenheilk 2006; 66: 999-1001

37 Berg D. Essentials der neuen S1-Leitlinie zum Umgang mit Frauen nach sexueller Gewalt. Geburtsh Frauenheilk 2010; 70: 151

38 Ingram DL, Everett VD, Lyna PR et al. Epidemiology of adult sexually transmitted disease agents in children being evaluated for sexual abuse. Pediatr Infect Dis J 1992; 11: 945-950

39 Herrera Saval A, Rodriguez Picardo A, Garcio Bravo B. Verruces anogenitales chez les enfants. Ann Dermatol Venereol 1990; 117: 523-526

40 Obalek S, Misiewicz J, Jablonska S. Childhood condylomata acuminate: association with genital and cutaneous human papillomavirus. Pediatr Dermatol 1993; 10: 101-106

41 Stevens-Simon C, Nelligan D, Breese Pet al. The prevalence of genital human papillomavirus infections in abused and non-abused preadolescent girls. Pediatr 2000; 106: 645-649

42 Thyen $U$, Herrmann B, Frank $R$, von Bismarck S. Leitlinie Kindesmisshandlung und Vernachlässigung der Deutschen Gesellschaft für Sozialpädiatrie und Jugendmedizin, der Deutschen Gesellschaft für Kinderheilkunde und Jugendmedizin und der Deutschen Gesellschaft für Kinderchirurgie 9/2008. http://www.awmf.org/leitlinien/detail/1l/071003.html; last access: 1.8.2011

43 Wienert V, Breitkopf C, Furtwängler A et al. AWMF-Leitlinie Nr. 081/008. Leitlinie der Deutschen Gesellschaft für Koloproktologie (2008). Anale Feigwarzen. http://www.awmf.org/leitlinien/detail/1l/081-008.html; last access: 1 8.2011

44 Alken P, Altwein JE, Hertle L et al. Leitlinien zur Diagnostik und Therapie von Genitalerkrankungen durch Human papilloma viruses (HPV) der Deutschen Gesellschaft für Urologie. Der Urologe 2001; 6: 511-520

45 Friese K. AWMF Nr. 015/027 Leitlinie der Deutschen Gesellschaft für Gynäkologie und Geburtshilfe (DGGG) Prävention, Diagnostik und
Therapie der HPV-Infektion und präinvasiver Läsionen des weiblichen Genitale 2008. http://www.awmf.org/leitlinien/detail/11/015-027. html; last access: 1.8.2011

46 Bussen S, Herold A, Schmittner M et al. Koloproktologische Erkrankungen in der Schwangerschaft und dem Wochenbett. Geburtsh Frauenheilk 2008; 68: 1069-1073

47 Seidl S. Micropapillomatosis vulvae - eine fatale Fehldiagnose. Geburtsh Frauenheilk 2011; 71: 194-198

48 Tzellos TG, Sardelli C, Lallas A et al. Efficacy, safety and tolerability of green tea catechins in the treatment of external anogenital warts: a systematic analysis. J Eur Acad Dermatol Venereol 2001; 25: 345-353

49 Gross G. Polyphenon E. Hautarzt 2008; 59: 31-35

50 Tatti S, Stockfleth E, Beutner KR et al. Polyphenon E: a new treatment for external anogenital warts. Br J Dermatol 2010; 162: 176-184

51 Schaen L, Mercurio MG. Treatment of human papilloma virus in a 6 month-old infant with imiquimod 5\% cream. Pediatr Dermatol 2001; 18: $450-452$

52 Moresi JM, Herbert CR, Cohen BA. Treatment of anogenital warts in children with topical $0.05 \%$ podofilox gel and $5 \%$ imiquimod cream. Pediatr Dermatol 2001; 18: 448-450

53 Brandt HR, Patriota RC, Belda W et al. Treatment of human papillomavirus in childhood with imiquimod $5 \%$ cream. Ann Bras Dermatol 2009; 84: 549-553

54 Skowron C, Raoulx M, Skowron F. Topical imiquimod for the treatment of anogenital warts in an infant. Ann Dermatol Venereol 2010; 137: $622-625$

55 Colette-Villette AM, Gaudy-Marqueste C, Grob JJ et al. Carbon dioxide laser therapy for anogenital warts in children. Ann Dermatol Venereol 2007; 134: 829-832

56 Gesierich A, Hamm H, Bröcker EB et al. Mehrschichtige Argon-PlasmaKoagulation und Imiquimod-Crème: eine wenig invasive, aber ausreichend radikale Kombinationstherapie bei ausgedehnter bowenoider Papulose. Geburtsh Frauenheilk 2008; 68: 274-278

57 Wolf $R$, Davidovici $B$. Treatment of genital warts: facts and controversies. Clin Dermatol 2010; 28: 546-548

58 Center for Disease Control. Sexually transmitted diseases. Treatment guidelines 2010. Morbidity and mortality weekly report 2010; 59: RR-12 69-74. www.cdc.gov/mmwr; last access: 1.8.2011

59 Handsfield $\mathrm{HH}$. Clinical presentation and natural course of anogenital warts. Am J Med 1997; 102: 16-20

60 Ihnen M, Mahner S, Schwarz J. Regression von Condylomata acuminata in der Schwangerschaft nach systemischer Therapie mit Thuja. Geburtsh Frauenheilk 2006; 66: 179-182

61 Aynaund 0, Buffet $M$, Roman $P$ et al. Study of persistence and recurrence rates in 106 patients with condylomata and intraepithelial neoplasia after $\mathrm{CO}_{2}$ laser treatment. Eur J Dermatol 2008; 18: 153-158

62 Donovan B, Franklin N, Guy R et al. Quadrivalent human papillomavirus vaccination and trends in genital warts in Australia. Analysis of national sentinel surveillance data. Lancet Infect Dis 2011; 11: 39-44

63 Ständige Impfkommission. Empfehlung der STIKO zur HPV-Impfung. Epid Bull 2007; 12: 97-103

64 Ständige Impfkommission. Impfung gegen HPV - Aktuelle Bewertung der STIKO. Epid Bull 2009; 32: 319-338

65 Schmalfeldt B, Seifert-Klauss V, Paepke S et al. Beratung zur HPV-Impfung bei jungen sexuell aktiven Frauen. Geburtsh Frauenheilk 2008; 68: $27-30$

66 Doubek K. HPV-Impfung: Wie ist die Akzeptanz - eine Bilanz. Geburtsh Frauenheilk 2011; 71: 617-619

67 Schneider A, Kaufmann AM. Prophylaktische HPV-Vakzinierung - der Hoffnungsträger in der Prävention des Zervixkarzinoms - aktueller Stand. Geburtsh Frauenheilk 2007; 67: 19-21

68 Gross G, Gissmann L, Hillemann P et al. Die Impfprävention HPV-assoziierter Neoplasien - eine Zusammenfassung der deutschen S3-Leitlinie. Dtsch Med Wochenschr 2010; 135: 1083-1086

69 Kaplan R, Adams JA, Statling SP et al. Medical response to child sexual abuse. A ressource for professionals working with children and families. St. Louis: STM Learning; 2011: 180-187

70 Hermann B, Dettmeyer R, Banaschak S et al. Kindesmisshandlung. Medizinische Diagnostik, Intervention und rechtliche Grundlagen. 2. Aufl. Heidelberg, Berlin, New York: Springer Verlag; 160-162, 334

Deutschsprachige Zusatzinformationen mit deutschem Text online abrufbar unter: www.thieme-connect.de/ejournals/toc/gebfra. 